\title{
A Statistical Assessment of the Impact of Agricultural Land Use Intensity on Regional Surface Water Quality at Multiple Scales
}

\author{
Weiwei Zhang ${ }^{1}$, Hong $\mathrm{Li}^{1}{ }^{1} *$, Danfeng Sun ${ }^{2}$ and Liandi Zhou ${ }^{1}$ \\ 1 Institute of Agricultural Integrated Development, Beijing Academy of Agriculture and Forestry \\ Sciences, No.9 Shu Guang Hua Yuan Middle Road, Beijing 100097, China; \\ E-Mails: zhangwei492@163.com (W.Z.); liandizhou@126.com (L.Z.) \\ 2 College of Natural Resources and Environmental Science, China Agricultural University, Beijing \\ 100094, China; E-Mail: sundf@cau.edu.cn
}

* Author to whom correspondence should be addressed; E-Mail: lihsdf@ sina.com; Tel.: +86-10-5150-3175; Fax: +86-10-8843-0926.

Received: 27 August 2012; in revised form: 29 October 2012 / Accepted: 9 November 2012 / Published: 15 November 2012

\begin{abstract}
Understanding the effects of intensive agricultural land use activities on water resources is essential for natural resource management and environmental improvement. In this paper, multi-scale nested watersheds were delineated and the relationships between two representative water quality indexes and agricultural land use intensity were assessed and quantified for the year 2000 using multi-scale regression analysis. The results show that the log-transformed nitrate-nitrogen $\left(\mathrm{NO}_{3}-\mathrm{N}\right)$ index exhibited a relationship with chemical fertilizer input intensity and several natural factors, including soil loss, rainfall and sunlight at the first order watershed scale, while permanganate index $\left(\mathrm{COD}_{\mathrm{Mn}}\right)$ had a positive relationship with another two input intensities of pesticides and agricultural plastic mulch and organic manure at the fifth order watershed scale. The first order watershed and the fifth order watershed were considered as the watershed adaptive response units for $\mathrm{NO}_{3}-\mathrm{N}$ and $\mathrm{COD}_{\mathrm{Mn}}$, respectively. The adjustment of agricultural input and its intensity may be carried out inside the individual watershed adaptive response unit. The multiple linear regression model demonstrated the cause-and-effect relationship between agricultural land use intensity and stream water quality at multiple scales, which is an important factor for the maintenance of stream water quality.
\end{abstract}


Keywords: agricultural land use intensity; water quality; multi-scale; linear regression

\section{Introduction}

Land use intensity is one of the most significant forms of land cover modification, and can have a major detrimental impact on terrestrial and aquatic ecosystems [1,2], and also directly influence human and ecosystem health. Many developed countries are experiencing environmental pollution due to intensive agricultural activities, including intensive crop and livestock production [3]. This is also the true for the fast developing countries, such as China. From a land use perspective, intensive agricultural activities have been identified as the major sources of non-point source pollutants and are known to alter and impact the quality of the receiving water bodies. As an environmental factors that relate directly to human health, water quality is always subject to degradation when agricultural land use intensity is too high [4]. Thus, understanding the effects of intensive agricultural land use activities on water resources is essential for natural resource management and environmental improvement. However, these effects on water quality conditions are difficult to determine because of the complex relationships between agricultural land use activities and water quality.

In previous studies water quality was generally linked to land use inside the catchments area. Several studies have found that land use has a strong influence on the receiving water body quality [5-7]. The majority of studies about the effects of land use on water quality have focused on either deterministic modeling, or spatial, or statistical analyses. Examples of modeling studies include those performed by Tong and Chen [5], Chaplot et al. [8], Cao et al. [9], Bhattarai et al. [10], etc. which have adopted the existing watershed-scale hydrological variables and nonpoint-source pollution models to evaluate or predict how land use/land cover scenarios affect water quality. Since modeling methods need long-term water quality monitoring data and regional parameters are difficult to obtain, current modeling methods are still developmental and confined to mechanism studies in local watersheds. Consequently, there are more studies that have adopted statistical methods such as correlation analysis [11,12], single linear regression analysis [13,14], multiple linear regression analysis [15-17], nonparametric statistical analysis techniques [18], etc. to examine the relationships between watershed land use/land cover and water quality.

Since no statistical significant relationships between land uses and nitrate level were found when using the whole basins, contributing areas inside buffer zones were developed by Basnyat et al [19]. There have been more subsequent studies taking buffer zones as analysis units to explore water quality characteristics and their relationships [20-22]. The definition of contributing zone may open additional ways of visualizing the problem. The previous studies have demonstrated that the contributing zone is influenced by many factors, including the water-quality parameter being assessed and geomorphic/climatic setting of the watershed [19]. To some extent, buffer zones with multi-scale characteristics, created using the distance from the stream, are not true hydrological units, and they are difficult to delineate and explain the hydrological and ecological condition of the stream validly. To overcome this, our study defines the multi-scale nested watersheds based on the basic watershed units created by a digital elevation model for the purpose of more effective watershed management, and multi-scale analysis is adopted to 
explore the relationships between agricultural land use intensity and water quality, and further to identify watershed adaptive response units for every water quality parameter.

Beijing's mountainous watersheds, providing $69.9 \%$ of its surface water resources, have played increasingly important roles in drinking water supply and headwater conservation considering the population increase and urban sprawl of Beijing. Moreover, land use changes in the Beijing mountainous areas have brought about many land related problems, such as water pollution, soil contamination and air pollution [23]. We had adopted emergy analysis with principal component analysis, regression analysis and cluster classification to investigate the characteristics and patterns of agricultural land use intensity of study areas in 2000, as the baseline of ecological monitoring and assessment [24]. However, the effects of the agricultural land use intensity on surface water quality have not been discussed. Therefore, the objective of this study, taking the Beijing mountainous area as a case, was to investigate the impacts of agricultural land use intensity on selected physical properties of surface water quality using multi-scale analysis for building a baseline database applicable to long-term monitoring.

\section{Materials and Methods}

\subsection{Study Areas}

Beijing's mountainous areas, with an area of $1.04 \times 10^{6}$ ha, are located to the west, north and northeast of Beijing. The study areas comprise a total of five rivers, including the Yongding River, Chaobai River, Beiyun River, Jiyun River and Daqing River (Figure 1). Mean annual precipitation in the area is about $566 \mathrm{~mm}$, about $60 \%$ of which falls in July and August. The annual average evaporation is about $1,761 \mathrm{~mm}$. Annual average runoff was about $1.8 \times 10^{9} \mathrm{~m}^{3}$, but this had decreased to $1.3 \times 10^{9} \mathrm{~m}^{3}$ by the end of the last century as a result of climate and land use/land cover changes.

Figure 1. Study area and monitoring sites.

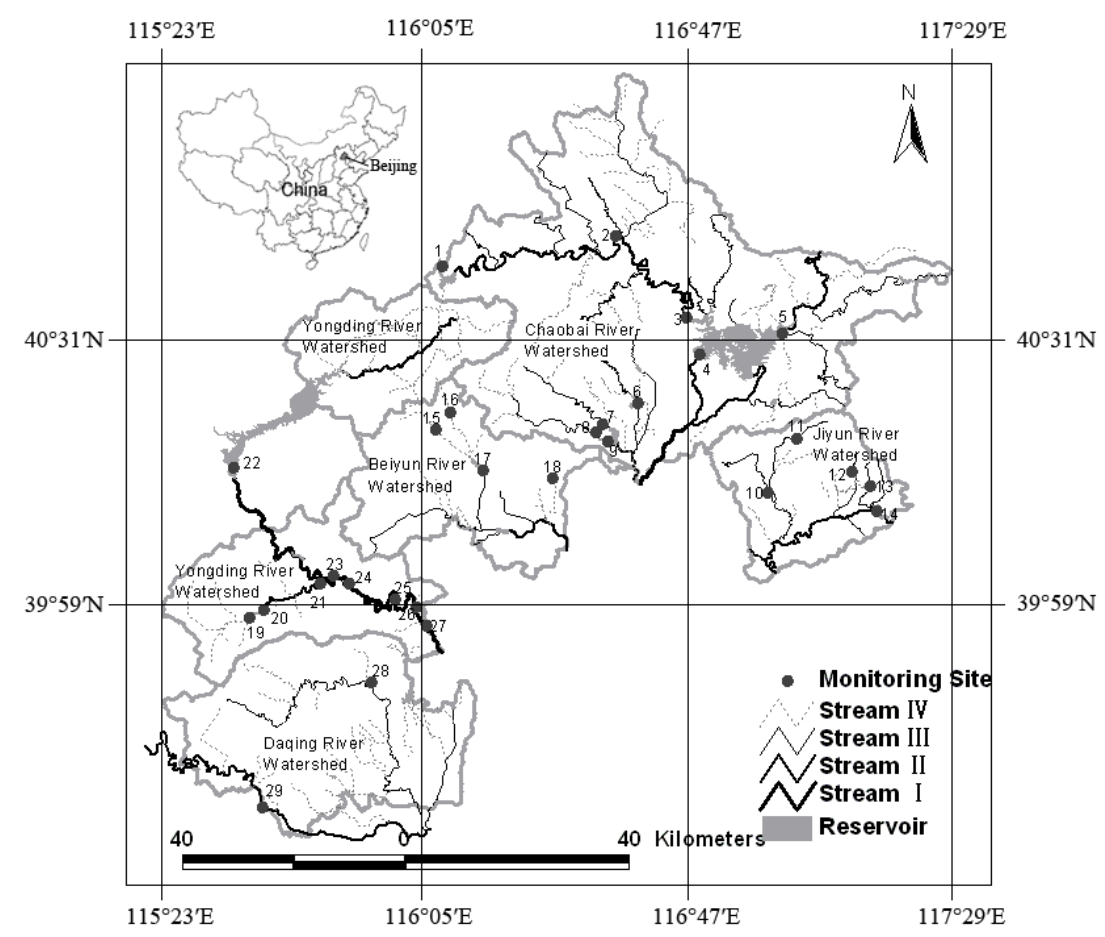


With the population increase and urban sprawl of Beijing, mountain agriculture has played increasingly important roles in areas such as services, the economy, ecological security and tourism. Figure 2 shows that the gross value of agricultural output in the study area increased quickly with the pressure for arable land resources in plain areas that have become non-agricultural land owing to city sprawl, particularly in the high development periods of the mid 1990s. The past studies suggested that the increase in agricultural output mainly depended on the input of a large amount of non-renewable resources, especially agricultural chemical fertilizers, pesticides and plastic film, according to the correlation analyses of agricultural inputs and outputs in 2000 [24]. The main non-renewable agricultural inputs have still increased in recent decade years, which has led to greatly increased environmental damage such as water pollution, soil contamination and air pollution caused by agriculture, especially high intensity industrialized agriculture.

Figure 2. Gross agricultural output for the Beijing mountainous areas.

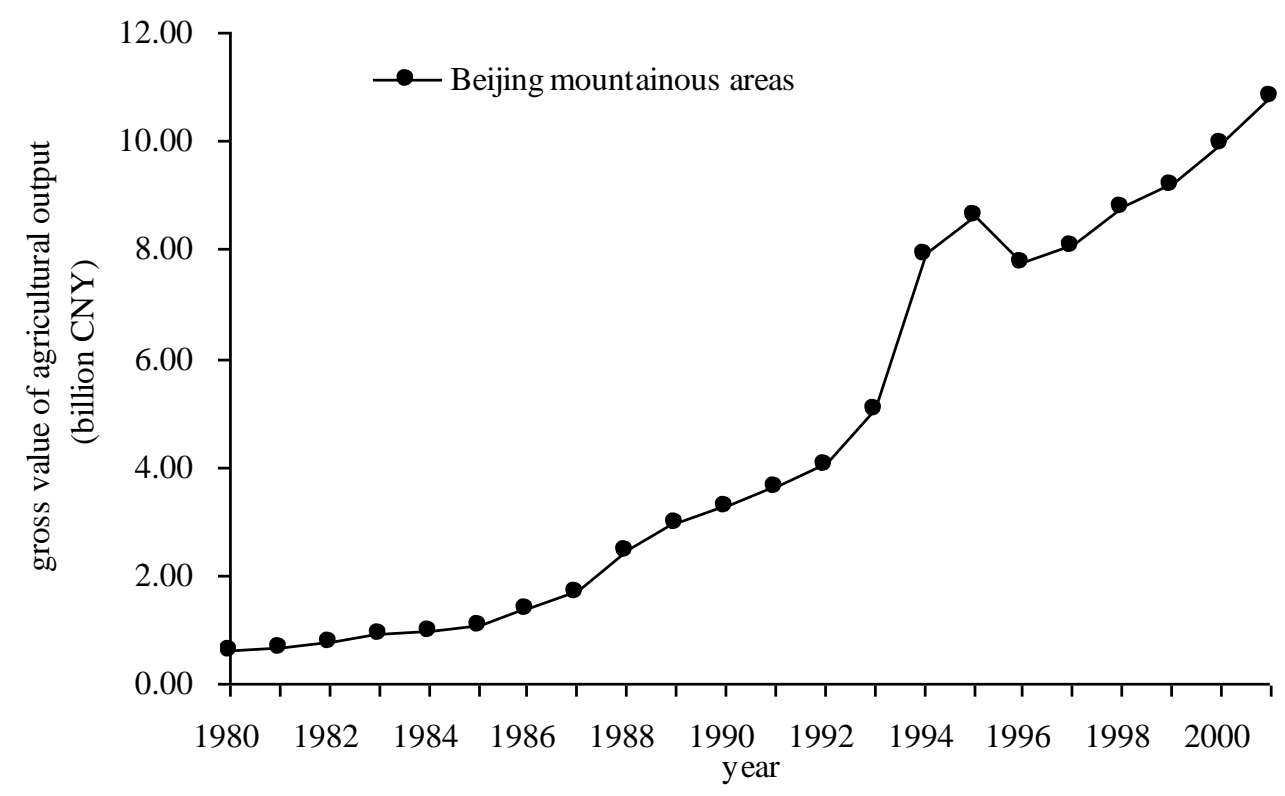

\subsection{Surface Water Quality Data}

There are 27 monitoring sites in the study area. The monitoring Sites 1-8, 9-13, 14-17, 18-25 and 26-27 correspond to the Chaobai River, Juyun River, Beiyun River, Yongding River and Daqing River watersheds, respectively (Figure 1). The streams on which they are respectively located are listed in Table 1. Water samples were taken at these stations monthly from May to October 2000. Of these, June, July, August and November in 2000 were the rainy reason, and the rest was the dry season. A total of 162 samples were collected at the 27 sites of the Beijing mountainous areas. Water samples were analyzed in the laboratory for eight water quality characteristics, including nitrate-nitrogen $\left(\mathrm{NO}_{3}-\mathrm{N}\right)$, permanganate index $\left(\mathrm{COD}_{\mathrm{Mn}}\right)$, biochemical oxygen demand for five days $\left(\mathrm{BOD}_{5}\right)$, total nitrogen $(\mathrm{TN})$, total phosphorus $(\mathrm{TP})$, total mercury $(\mathrm{Hg})$, total cadmium $(\mathrm{Cd})$ and total lead $(\mathrm{Pb})$. Then the monthly average values of water quality characteristics for each site were derived, which were used for our statistical assessment. 
Table 1. The streams and watersheds of the 27 monitoring sites.

\begin{tabular}{|c|c|c|}
\hline Watersheds & Stream & Site \\
\hline \multirow{6}{*}{ Chaobai River } & Bai River & $1-3$ \\
\hline & Chao River & 4 \\
\hline & Yanqi River & 5 \\
\hline & Huaisha River & 6 \\
\hline & Huaijiu River & 7 \\
\hline & Huai River & 8 \\
\hline \multirow{5}{*}{ Jiyun River } & Cuo River & 9 \\
\hline & Zhenluoying Rock River & 10 \\
\hline & Huangsongyu Rock River & 11 \\
\hline & Jiangjunguan Rock River & 12 \\
\hline & Ju River & 13 \\
\hline \multirow{4}{*}{ Beiyun River } & Deshengkou Ditch & 14 \\
\hline & Zhuishikou Ditch & 15 \\
\hline & Dongsha River & 16 \\
\hline & Qintun River & 17 \\
\hline \multirow{2}{*}{ Yongding River } & Qingshui River & $18-20$ \\
\hline & Yongding River & $21-25$ \\
\hline \multirow{2}{*}{ Daqing River } & Dashi River & 26 \\
\hline & Juma River & 27 \\
\hline
\end{tabular}

The surface water quality characteristics $\mathrm{NO}_{3}-\mathrm{N}$ and $\mathrm{COD}_{\mathrm{Mn}}$ have been considered as two of the four water pollutant load control indexes in China. Furthermore, the relationship between water quality characteristics was tested at the significance levels of $p<0.01$ and 0.05 , which showed that $\mathrm{NO}_{3}-\mathrm{N}$ had a high positive correlation with $\mathrm{TN}, \mathrm{TP}, \mathrm{Hg}, \mathrm{Cd}$ and $\mathrm{Pb}$, and $\mathrm{COD}_{\mathrm{Mn}}$ had a positive correlation with $\mathrm{Hg}, \mathrm{Cd}$ and $\mathrm{Pb}$ (Table 2).

Therefore, we focused on the two conventional water quality characteristics $\mathrm{NO}_{3}-\mathrm{N}$ and $\mathrm{COD}_{\mathrm{Mn}}$, which not only can reduce the complexity of the study, but also is of great significance for water resources management.

Table 2. Bivariate correlation coefficients of water quality variables.

\begin{tabular}{ccccccccc}
\hline & $\mathbf{N O}_{3}-\mathbf{N}$ & $\mathbf{C O D}_{\mathbf{M n}}$ & $\mathbf{B O D}_{\mathbf{5}}$ & $\mathbf{H g}$ & $\mathbf{C d}$ & $\mathbf{P b}$ & $\mathbf{T N}$ & $\mathbf{T P}$ \\
\hline $\mathrm{NO}_{3}-\mathrm{N}$ & 1 & & & & & & & \\
$\mathrm{COD}_{\mathrm{Mn}}$ & $0.607^{\mathrm{b}}$ & 1 & & & & & & \\
$\mathrm{BOD}_{5}$ & 0.655 & -0.034 & 1 & & & & & \\
$\mathrm{Hg}$ & $0.809^{\mathrm{b}}$ & $0.857^{\mathrm{b}}$ & -0.611 & 1 & & & & \\
$\mathrm{Cd}$ & $0.917^{\mathrm{b}}$ & $0.640^{\mathrm{b}}$ & -0.742 & $0.904^{\mathrm{b}}$ & 1 & & & \\
$\mathrm{~Pb}$ & $0.917^{\mathrm{b}}$ & $0.640^{\mathrm{b}}$ & -0.742 & $0.904^{\mathrm{b}}$ & $1.000^{\mathrm{b}}$ & 1 & & \\
$\mathrm{TN}$ & $0.996^{\mathrm{a}}$ & -0.829 & 0.587 & 0.282 & 0.107 & 0.107 & 1 & \\
$\mathrm{TP}$ & $0.999^{\mathrm{a}}$ & -0.805 & 0.621 & 0.242 & 0.065 & 0.065 & $0.999^{\mathrm{a}}$ & 1 \\
\hline
\end{tabular}

${ }^{\mathrm{a}}$ Significant at the 0.01 level. ${ }^{\mathrm{b}}$ Significant at the 0.05 level. 


\subsection{Multi-Scale Watershed Delineation}

\subsubsection{Basic Watershed Units}

A watershed is the up-slope area contributing flow to a given location. Such a feature is also variously referred to as a catchment or basin, and comprises a part of a hierarchy in that any given watershed is generally part of a larger watershed [19]. A digital elevation model (DEM) with $30 \mathrm{~m} \times 30 \mathrm{~m}$ grid resolution was adopted to create basic watershed units for the Beijing mountainous area using the hydrologic functions in the ArcView extensions. The minimum number of cells for a stream network in the hydrologic functions is very important for the watershed delineation. Many studies have shown that when the minimum number of cells was smaller, the extracted stream networks were denser, and the created basin areas were smaller. The stream network extracted by hydrologic functions should be similar to that existing in Nature, and each of the monitoring sites should be located at the pour point of different basic watershed units for the purpose of this study. Therefore, the thresholds of 15,000, $12,000,10,000,8,000$ and 5,000 were chosen as the minimum number of cells for a stream network during the test of basic watershed unit creation. The results indicated that a few monitoring sites were located in the same basic watershed unit when the thresholds was bigger than 10,000, and the stream networks extracted were far denser than natural stream network when the threshold was less than 10,000. Ultimately, the thresholds of 10,000, i.e., 900 ha, which is far smaller than the average area of the Beijing mountain towns $(9,285$ ha), was determined as the minimum number of cells for a stream network to delineate basic watershed units (Figure 3).

Figure 3. Basic watershed units delineated in the study area.

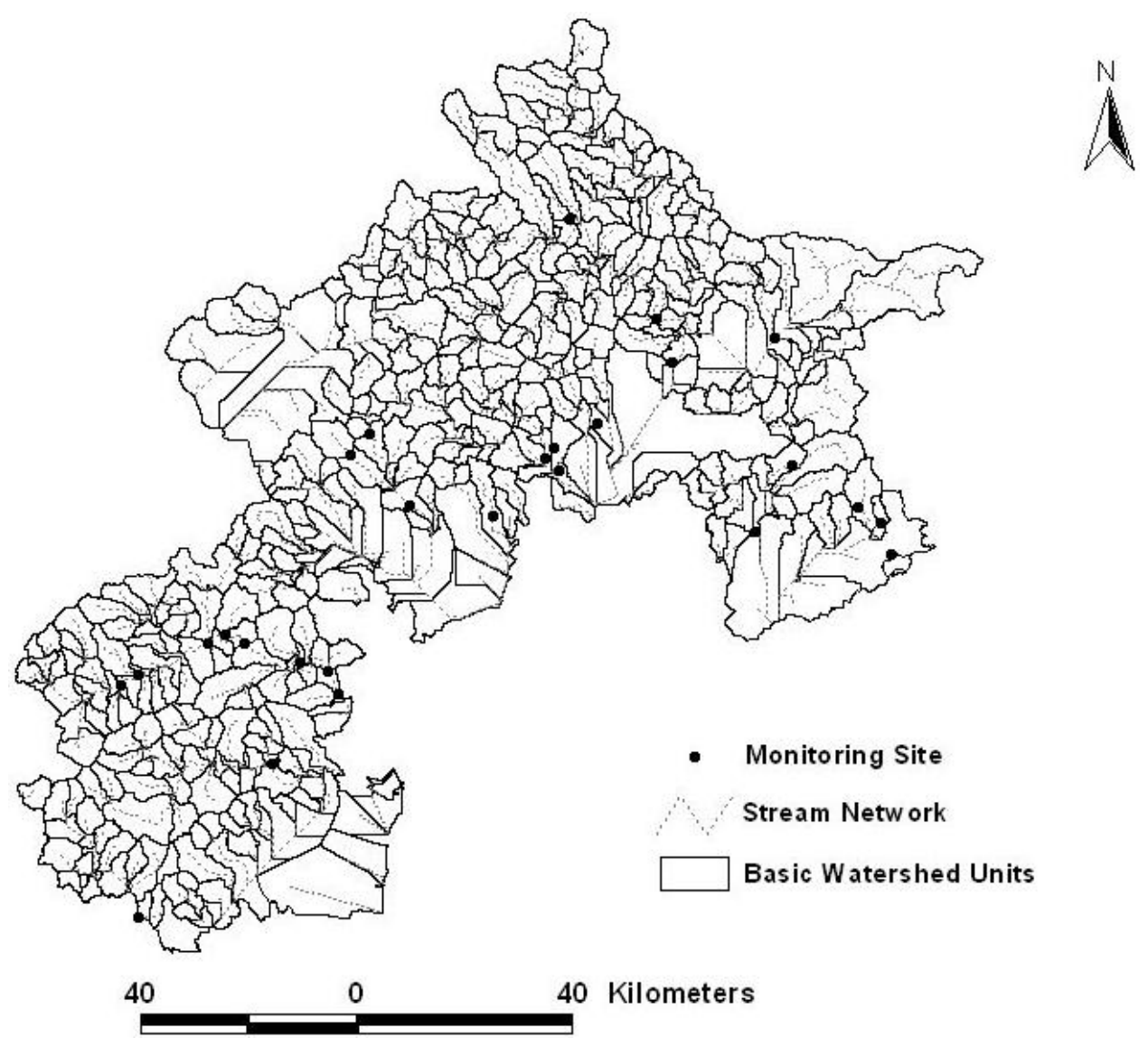




\subsubsection{Delineating Multi-Scale Watersheds as Watershed Analysis Units}

Multi-scale watersheds corresponding to the 27 monitoring sites were identified as watershed analysis units for further analysis according to the flow direction and rivers, respectively. Since some monitoring sites are located on the same streams, such as Sites 1-3 (Bai River), Sites 18-20 (Qingshui River) and Sites 21-25 (Yongding River), perhaps they are statistically highly correlated and, to some extent, all the upstream points contribute to the measurements of any monitoring point. This is statistically undesirable and would produce strongly biased results. To solve this problem, the independence of these sites' data should be tested. A serial autocorrelation test was adopted to analyze the possible correlation between neighboring sites. The test results showed that these upstream monitoring sites had little contribution to their nearest downstream sites for $\mathrm{NO}_{3}-\mathrm{N}$ and $\mathrm{COD}_{\mathrm{Mn}}$ water quality data in 2000. Therefore, the monitoring samples can be considered independent for further statistical analysis, and the watersheds contributing flow to these sites cannot be included in the their nearest downstream sites' watersheds when delineating the watershed analysis units.

Figure 4. The whole watersheds for the 27 monitoring sites.

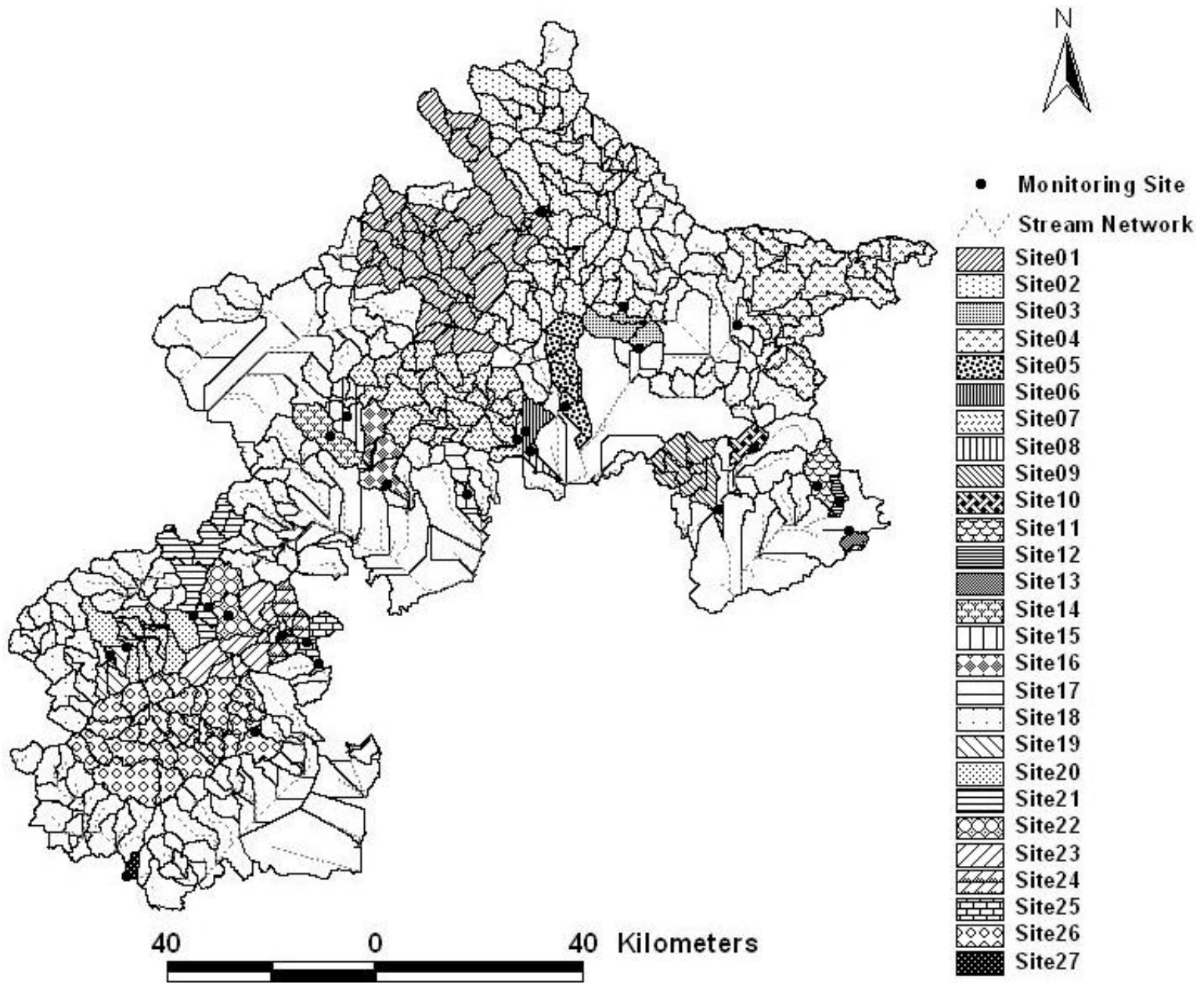

Firstly, the basic watershed units contributing flow to every monitoring site were delineated as the whole watershed of every monitoring site, which did not have a nest relation according to the result of serial autocorrelation test mentioned above (Figure 4). Table 3 shows the number of towns covered by the whole watershed for every monitoring site. Subsequently, multi-scale watersheds were determined 
in the whole watershed area of every monitoring site. The basic watershed units directly contributing flow to every monitoring site were considered as the first order watershed (Zone 1). The Zone 1 and the basic watershed units directly contributing flow to the Zone 1 were together defined as second order watershed (Zone 2). By analogy, the next order watersheds were derived and named in order third order watershed (Zone 3), fourth order watershed (Zone 4) and fifth order watershed (Zone 5), etc. Figure 5 illustrates the process of delineating multi-scale watersheds for Site 1. Table 3 also lists the number of scales for every monitoring site.

Figure 5. Illustration of how the multi-scale watersheds were defined: (a) The whole watershed for Site 1. (b) Definition of the Zone 1. (c) Definition of the Zone 2. (d) Definition of the Zone 3. (e) Definition of the Zone 4. (f) Definition of the Zone 5.

a

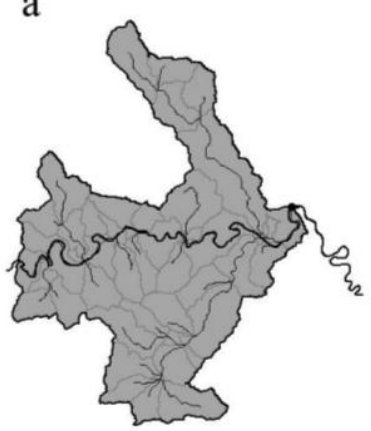

d

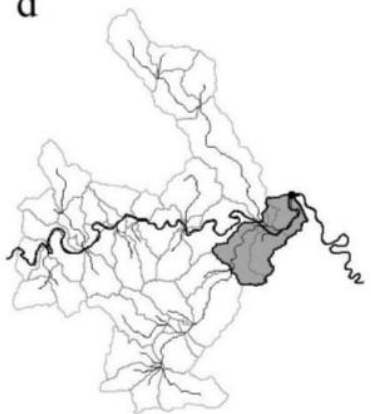

$\mathrm{b}$

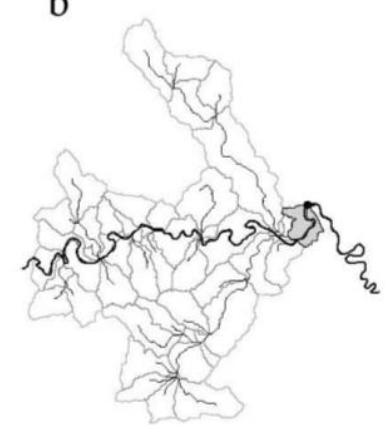

e

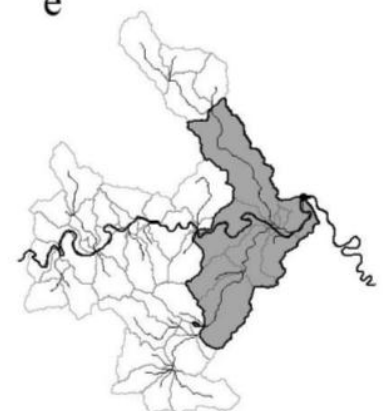

c

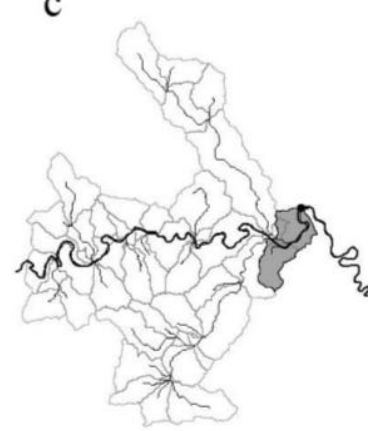

$\mathrm{f}$

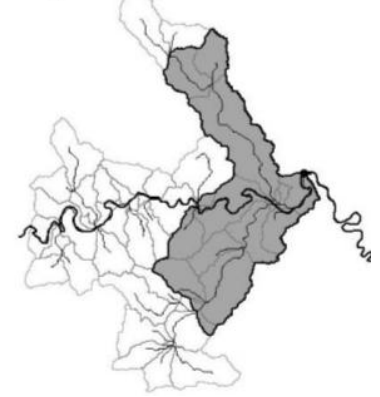

Table 3. The number of scales and towns be covered for 27 monitoring sites.

\begin{tabular}{ccc|ccc}
\hline Site & Towns & Scale & Site & Towns & Scale \\
\hline 1 & 6 & $>10$ & 14 & 3 & 1 \\
2 & 7 & $>10$ & 15 & 2 & 3 \\
3 & 2 & 2 & 16 & 4 & 4 \\
4 & 6 & 7 & 17 & 1 & 2 \\
5 & 4 & 3 & 18 & 1 & 7 \\
6 & 2 & 1 & 19 & 2 & 3 \\
7 & 5 & 10 & 20 & 2 & 8 \\
8 & 3 & 1 & 21 & 2 & 4 \\
9 & 4 & 5 & 22 & 2 & 2 \\
10 & 2 & 1 & 23 & 4 & 6 \\
11 & 4 & 1 & 24 & 4 & 3 \\
12 & 3 & 1 & 25 & 2 & 2 \\
13 & 2 & 1 & 26 & 8 & $>10$ \\
& & & 27 & 1 & 1 \\
\hline
\end{tabular}




\subsection{Agricultural Land Use Intensity for Watershed}

With more attention being paid to land use and land cover change, an approach to assess agricultural land use intensity including agricultural input and output intensity on a general basis has been developed in our previous work [24]. The measurement and assessment of agricultural land use intensity was preformed at municipal/town level because the agricultural inputs and outputs information derived from census data are aggregated and officially reported at this level, and this level also is the smallest administrative unit as planning and management purpose in China. Four indices of agricultural input intensity and six of output intensity have been derived with principal component analysis at this level for the Beijing mountainous areas using the amount of emergy of each agricultural input and output derived from agricultural census data [24]. Their eigenvectors are given in Tables 4 and 5. The several indices reflecting agricultural input and output intensity were dimensionless, and the meanings of these indices according to their eigenvectors are shown in Table 6. The higher the index value, the greater the agricultural input or output intensity.

Table 4. Eigenvectors of the input intensity [24].

\begin{tabular}{ccccc}
\hline Components & IPC $_{\mathbf{1}}$ & $\mathbf{I P C}_{\mathbf{2}}$ & $\mathbf{I P C}_{\mathbf{3}}$ & $\mathbf{I P C}_{\mathbf{4}}$ \\
\hline Sunlight & 0.990 & -0.075 & -0.083 & 0.018 \\
Rain, chemical energy & 0.983 & -0.056 & -0.086 & 0.070 \\
Rain, geopotencial energy & 0.932 & -0.163 & -0.159 & -0.096 \\
Earth cycle & 0.991 & -0.071 & -0.086 & 0.028 \\
Wind, kinetic energy & 0.991 & -0.071 & -0.086 & 0.028 \\
Soil loss & 0.991 & -0.071 & -0.086 & 0.028 \\
Agricultural electricity & -0.252 & 0.364 & 0.527 & 0.156 \\
Nitrogen fertilizer & -0.102 & 0.792 & 0.165 & 0.448 \\
Phosphorus fertilizer & -0.062 & 0.852 & 0.011 & 0.305 \\
Potash fertilizer & -0.103 & 0.890 & 0.113 & 0.139 \\
Compound fertilizer & -0.119 & 0.809 & 0.270 & 0.184 \\
Pesticides & 0.005 & 0.109 & 0.787 & -0.103 \\
Agricultural plastic mulch & -0.165 & -0.024 & 0.673 & 0.180 \\
Machinery power & 0.003 & 0.619 & 0.348 & -0.085 \\
Human labor & 0.140 & 0.344 & 0.620 & 0.494 \\
Livestock labor & 0.135 & 0.020 & -0.034 & 0.875 \\
Organic manure & -0.088 & 0.471 & 0.268 & 0.648 \\
Seed & -0.090 & 0.761 & 0.234 & 0.425 \\
\hline
\end{tabular}

Table 5. Eigenvectors of the output intensity [24].

\begin{tabular}{ccccccc}
\hline Components & $\mathbf{O P C}_{\mathbf{1}}$ & $\mathbf{O P C}_{\mathbf{2}}$ & $\mathbf{O P C}_{\mathbf{3}}$ & $\mathbf{O P C}_{\mathbf{4}}$ & $\mathbf{O P C}_{\mathbf{5}}$ & $\mathbf{O P C}_{\mathbf{6}}$ \\
\hline Grain crops & 0.569 & 0.423 & 0.258 & 0.186 & 0.055 & 0.045 \\
Oil crops & -0.021 & -0.003 & -0.050 & 0.911 & 0.056 & 0.046 \\
Vegetables & 0.761 & 0.136 & -0.105 & -0.156 & -0.028 & -0.092 \\
Fruits & -0.077 & -0.088 & 0.867 & -0.131 & 0.088 & 0.064 \\
Pork & 0.682 & 0.228 & 0.226 & 0.325 & 0.187 & -0.033 \\
Beef & 0.240 & 0.792 & -0.061 & 0.063 & -0.139 & 0.096 \\
\hline
\end{tabular}


Table 5. Cont.

\begin{tabular}{ccccccc}
\hline Components & $\mathbf{O P C}_{\mathbf{1}}$ & $\mathbf{O P C}_{\mathbf{2}}$ & $\mathbf{O P C}_{\mathbf{3}}$ & $\mathbf{O P C}_{\mathbf{4}}$ & $\mathbf{O P C}_{\mathbf{5}}$ & $\mathbf{O P C}_{\mathbf{6}}$ \\
\hline Mutton & -0.053 & 0.109 & 0.069 & 0.050 & 0.021 & 0.967 \\
Fowl & 0.359 & 0.094 & 0.548 & 0.389 & -0.175 & -0.002 \\
Milks & 0.097 & 0.855 & -0.026 & -0.071 & 0.146 & 0.008 \\
Eggs & 0.815 & 0.111 & -0.038 & 0.003 & 0.055 & -0.124 \\
Forest logging & 0.062 & 0.036 & 0.026 & 0.048 & 0.968 & 0.020 \\
Fish & 0.781 & -0.237 & -0.077 & -0.120 & -0.101 & 0.225 \\
\hline
\end{tabular}

Table 6. The indices of agricultural input and output intensity.

\begin{tabular}{|c|c|c|c|}
\hline & $\begin{array}{l}\text { Indices at } \\
\text { town level }\end{array}$ & Meanings & $\begin{array}{c}\text { Indices at } \\
\text { watershed level }\end{array}$ \\
\hline \multirow{4}{*}{$\begin{array}{l}\text { Agricultural } \\
\text { input } \\
\text { intensity }\end{array}$} & $\mathrm{IPC}_{1}$ & $\begin{array}{l}\text { Natural factors, } \\
\text { including soil loss, rainfall and sunlight }\end{array}$ & $\mathrm{WI}^{-\mathrm{IPC}_{1}}$ \\
\hline & $\mathrm{IPC}_{2}$ & Chemical fertilizer, seed and mechanized power & WI-IPC ${ }_{2}$ \\
\hline & $\mathrm{IPC}_{3}$ & $\begin{array}{l}\text { Pesticides, agricultural plastic mulch, human } \\
\text { labor and agricultural electricity }\end{array}$ & WI-IPC 3 \\
\hline & $\mathrm{IPC}_{4}$ & Organic manure & $\mathrm{WI}-\mathrm{IPC}_{4}$ \\
\hline \multirow{6}{*}{$\begin{array}{c}\text { Agricultural } \\
\text { output } \\
\text { intensity }\end{array}$} & $\mathrm{OPC}_{1}$ & Eggs, vegetables, pork and grain crops & $\mathrm{WI}-\mathrm{OPC}_{1}$ \\
\hline & $\mathrm{OPC}_{2}$ & Milks and beef & WI-OPC 2 \\
\hline & $\mathrm{OPC}_{3}$ & Fruits and fowl & WI-OPC 3 \\
\hline & $\mathrm{OPC}_{4}$ & Oil crops & $\mathrm{WI}_{-} \mathrm{OPC}_{4}$ \\
\hline & $\mathrm{OPC}_{5}$ & Forest cut & $\mathrm{WI}^{-O P C}{ }_{5}$ \\
\hline & $\mathrm{OPC}_{6}$ & Sheep & ${\mathrm{WI}-\mathrm{OPC}_{6}}$ \\
\hline
\end{tabular}

For watershed-scale analysis, the indices of agricultural input and output intensity should be translated from the municipal/town level to the watershed level. Because there is a spatial incompatibility between the watershed analysis unit and the municipal/town unit, the weighted values with the percentage of town's agricultural land area in the watershed analysis unit were used as the weights to calculate the agricultural land use intensity indices for watershed analysis unit, which is as follows:

$$
W U I_{i}=\sum_{j=1}^{n} \% W T_{j} \cdot T U I_{j}
$$

where $W U I_{i}$ are the agricultural input and output indices for the watershed analysis unit $i, \% W T_{j}$ is the percentage of town $j$ 's agricultural land area in a watershed analysis unit $i . T U I_{j}$ is the agricultural input and output indices for town $j$. Therefore, the indices for watershed analysis unit $i$ were the weighted values with agricultural land area percentage used to reflect agricultural input and output intensity at every watershed scale.

\subsection{Agricultural Land Use Intensity and Water Quality Linkage}

The question of a relationship between agricultural land use intensity and water quality was examined at various scales by applying multiple regression techniques considering nutrient 
concentrations as dependent variables and the agricultural land use intensity as explanatory variables. The functional form of the relationship for each of these scales is as follows:

$$
N P S_{i}=f\left(W U I_{i}\right)
$$

where $N P S_{i}$ is nutrient concentration for monitoring site in question in watershed analysis unit $i, W U I_{i}$ is equal to the indices of agricultural input and output intensity for watershed analysis unit $i$.

In previous studies, the concentration of nutrients over an area can be described in the form of an exponential model or a linear model considering the proportions of land use/land cover as explanatory variables. Delivery of non-point source pollutants from discrete upstream contributing zones to a particular downstream point is a multi-step, often episodic, process [25]. A first order rate equation can be used for modeling nutrient attenuation in flow through various land uses to the nearest stream [25]. Since agricultural land use intensity has been one of the most significant forms of land cover modification, the exponential model was chosen for this research to explore the relationship between agricultural land use intensity and water quality, and to recognize how agricultural land use intensity affects water quality at various watershed scales. Stepwise multiple regression analysis was performed using $\log$ transformed dependent variables to reduce the asymmetric distribution of the data. The numbers of scales for 27 monitoring sites were different, thus, the used monitoring sites and sample number at various scales were different in the multi-scale regression analyses (Table 7). Because the sample numbers were too small to make valuable regression analysis above the scale of Zone 5, the multi-scale regression analyses were carried out with SPSS 13.0 at the scales from Zone 1 to Zone 5. Based on this statistical analysis, watershed adaptive response units for each water quality variable can also be identified.

Table 7. The monitoring sites at various scale level in the multi-scale analyses.

\begin{tabular}{ccc}
\hline Scale & Sites & Number \\
\hline Zone 1 & $1,2,3,4,5,6,7,8,9,10,11,12,13,14,15,16,17,18,19,20,21$, & 27 \\
Zone 2 & $22,23,24,25,26,27$ & 17 \\
Zone 3 & $1,2,3,4,5,7,9,15,16,19,20,21,22,23,24,25,26$ & 14 \\
Zone 4 & $1,2,4,5,7,9,15,16,19,20,21,23,24,26$ & 10 \\
Zone 5 & $1,2,4,7,9,16,20,21,23,26$ & 8 \\
Zone 6 & $1,2,4,7,9,20,23,26$ & 7 \\
Zone 7 & $1,2,4,7,20,23,26$ & 6 \\
>Zone 7 & $1,2,4,7,20,26$ & $<5$ \\
\hline
\end{tabular}

\section{Results}

\subsection{Water Quality Assessment}

Table 8 shows the 2000 yearly mean concentration of $\mathrm{NO}_{3}-\mathrm{N}$ and $\mathrm{COD}_{\mathrm{Mn}}$. The concentration of $\mathrm{NO}_{3}-\mathrm{N}$ in the samples ranged from 0.46 to $12 \mathrm{mg} / \mathrm{L}$, while $\mathrm{COD}_{\mathrm{Mn}}$ ranged from 1 to $7.4 \mathrm{mg} / \mathrm{L}$. Only the concentration of $\mathrm{NO}_{3}-\mathrm{N}$ for Site 12 exceeded to $10 \mathrm{mg} / \mathrm{L}$, which is the Chinese surface drinking water standard limit. Different from $\mathrm{NO}_{3}-\mathrm{N}$, there are five types of surface water environmental quality standard for $\mathrm{COD}_{\mathrm{Mn}}$. Since type IV and V cannot be acceptable for drinking 
water, the type III recommended value of $6 \mathrm{mg} / \mathrm{L}$ is considered as the surface drinking water standard limit for $\mathrm{COD}_{\mathrm{Mn}}$. According to this standard limit of $6 \mathrm{mg} / \mathrm{L}$, Site 12 was faced with organic contaminant and reducible inorganic substance drinking water pollution. Since Sites 10, 11, 17 and 22 were close to the standard limit of $6 \mathrm{mg} / \mathrm{L}$, especially Site 10, they also had a pollution risk caused by $\mathrm{COD}_{\mathrm{Mn}}$.

Table 8. The concentration of $\mathrm{NO}_{3}-\mathrm{N}$ and $\mathrm{COD}_{\mathrm{Mn}}$ in stream water of 27 monitoring sites.

\begin{tabular}{|c|c|c|c|c|c|c|}
\hline \multirow{2}{*}{$\begin{array}{l}\text { Monitoring } \\
\text { site }\end{array}$} & \multicolumn{3}{|c|}{$\mathrm{NO}_{3}-\mathrm{N}$} & \multicolumn{3}{|c|}{$\mathrm{COD}_{\mathrm{Mn}}$} \\
\hline & $\begin{array}{l}\mathrm{NO}_{3}-\mathrm{N} \\
(\mathrm{mg} / \mathrm{L})\end{array}$ & $\begin{array}{c}\text { Standard } \\
\text { limit }\end{array}$ & Type & $\begin{array}{c}\operatorname{COD}_{\mathrm{Mn}} \\
(\mathrm{mg} / \mathrm{L})\end{array}$ & $\begin{array}{c}\text { Standard } \\
\text { limit }\end{array}$ & Type \\
\hline 1 & 1.6 & 10 & Not exceeding & 2.4 & 4 & II \\
\hline 2 & 1.26 & 10 & Not exceeding & 2.2 & 4 & II \\
\hline 3 & 0.79 & 10 & Not exceeding & 2.3 & 4 & II \\
\hline 4 & 3.14 & 10 & Not exceeding & 2.1 & 4 & II \\
\hline 5 & 0.46 & 10 & Not exceeding & 3.2 & 4 & II \\
\hline 6 & 1.67 & 10 & Not exceeding & 1.9 & 2 & I \\
\hline 7 & 2.69 & 10 & Not exceeding & 1.5 & 2 & I \\
\hline 8 & 0.66 & 10 & Not exceeding & 2.5 & 4 & II \\
\hline 9 & 1.95 & 10 & Not exceeding & 1.5 & 2 & I \\
\hline 10 & 3.4 & 10 & Not exceeding & 6 & 6 & III * \\
\hline 11 & 2.57 & 10 & Not exceeding & 4.4 & 6 & III * \\
\hline 12 & 12 & 10 & Exceeding * & 7.4 & 10 & IV ** \\
\hline 13 & 1.09 & 10 & Not exceeding & 2.6 & 4 & II \\
\hline 14 & 0.86 & 10 & Not exceeding & 1.4 & 2 & I \\
\hline 15 & 1.06 & 10 & Not exceeding & 1.5 & 2 & I \\
\hline 16 & 0.37 & 10 & Not exceeding & 2.7 & 4 & II \\
\hline 17 & 0.18 & 10 & Not exceeding & 4.9 & 6 & III * \\
\hline 18 & 1.68 & 10 & Not exceeding & 1.4 & 2 & I \\
\hline 19 & 1.72 & 10 & Not exceeding & 3.2 & 4 & II \\
\hline 20 & 1.78 & 10 & Not exceeding & 1.3 & 2 & I \\
\hline 21 & 1.88 & 10 & Not exceeding & 2.1 & 4 & II \\
\hline 22 & 1.6 & 10 & Not exceeding & 4.4 & 6 & III * \\
\hline 23 & 1.33 & 10 & Not exceeding & 4 & 4 & II \\
\hline 24 & 1.51 & 10 & Not exceeding & 3.9 & 4 & II \\
\hline 25 & 1.51 & 10 & Not exceeding & 4 & 4 & II \\
\hline 26 & 3.51 & 10 & Not exceeding & 1 & 2 & I \\
\hline 27 & 1.76 & 10 & Not exceeding & 1.6 & 2 & $\mathrm{I}$ \\
\hline
\end{tabular}

\subsection{Linkage Model Results at Multiple Scales}

The regression models of $\mathrm{NO}_{3}-\mathrm{N}$ and $\mathrm{COD}_{\mathrm{Mn}}$ at the various watershed scales are shown in Table 9 and Table 10, respectively. The log-transformed $\mathrm{NO}_{3}-\mathrm{N}$ exhibited a relationship with WI-IPC 1 and WI-IPC ${ }_{2}$ at the scale of Zone 1, while no statistically significant relationships were found between agricultural land use intensity and nitrate level at the other watershed scales. The regression equation 
in the Zone 1 model, with the value 0.374 of $\mathrm{R}^{2}$ and the level 0.004 of statistical significance, is as follows:

$$
\ln \left(\mathrm{NO}_{3}-\mathrm{N}\right)=-0.026-0.901 \mathrm{WI}-\mathrm{IPC}_{1}+0.418 \mathrm{WI}-\mathrm{IPC}_{2}
$$

Although the coefficients of determination $\mathrm{R}^{2}$ is relatively weak, the model is statistically significant. The model suggests that natural factors act as sinks, and as the input intensity of natural factors including rainfall and sunlight inside the contributing zone (Zone 1) increases, $\mathrm{NO}_{3}-\mathrm{N}_{\text {levels }}$ downstream decrease. In addition, several artificial inputs, especially chemical fertilizer input, are identified as the second largest contributors of $\mathrm{NO}_{3}-\mathrm{N}$, and as chemical fertilizer input intensity within the contributing zone (Zone 1) increases, $\mathrm{NO}_{3}-\mathrm{N}$ levels downstream also increase.

Table 9. Multiple regression model of $\mathrm{NO}_{3}-\mathrm{N}$.

\begin{tabular}{cccccc}
\hline Scales & Variable in equation & Standardized Beta & $\mathbf{R}^{2}$ & Sig. & Number of samples \\
\hline \multirow{2}{*}{ Zone1 } & WI-IPC $_{1}$ & -0.469 & & & \\
& WI-IPC $_{2}$ & 0.412 & 0.374 & 0.004 & 27 \\
Zone2 & & & & 17 \\
Zone3 & & no variables were entered & & 14 \\
Zone4 & no variables were entered & & 10 \\
Zone5 & no variables were entered & & 8 \\
\hline
\end{tabular}

Table 10. Multiple regression model of $\mathrm{COD}_{\mathrm{Mn}}$.

\begin{tabular}{|c|c|c|c|c|c|}
\hline Scales & Variable in equation & Standardized Beta & $\mathbf{R}^{2}$ & Sig. & Number of samples \\
\hline Zone1 & \multicolumn{4}{|c|}{ no variables were entered } & 27 \\
\hline Zone2 & \multicolumn{4}{|c|}{ no variables were entered } & 17 \\
\hline Zone3 & \multicolumn{4}{|c|}{ no variables were entered } & 14 \\
\hline Zone4 & \multicolumn{4}{|c|}{ no variables were entered } & 10 \\
\hline \multirow{2}{*}{ Zone5 } & $\mathrm{WI}^{-\mathrm{IPC}_{3}}$ & 0.527 & \multirow{2}{*}{0.452} & \multirow{2}{*}{0.001} & \multirow{2}{*}{8} \\
\hline & $\mathrm{WI}^{-\mathrm{IPC}_{4}}$ & 0.085 & & & \\
\hline
\end{tabular}

For the water quality index $\mathrm{COD}_{\mathrm{Mn}}$, no variables were entered in the stepwise regression analysis for the scales from Zone 1 to Zone 4, while the most important explanatory variables were the WI-IPC 3 and $\mathrm{WI}-\mathrm{IPC}_{4}$ at the watershed scales of Zone 5 . The regression equation between agricultural land use intensity and permanganate index in the Zone 5 model, with the value 0.452 of $\mathrm{R}^{2}$ and the level 0.001 of statistical significance, is as follows:

$$
\ln \left(\mathrm{COD}_{\mathrm{Mn}}\right)=0.745+0.514 \mathrm{WI}-\mathrm{IPC}_{3}+0.052 \mathrm{WI}-\mathrm{IPC}_{4}
$$

In the regression model of permanganate index, the two input intensities of pesticides and agricultural plastic mulch and organic manure inside the contributing zone (Zone 5) both have the positive impact on the permanganate level downstream. Therefore, the input of pesticides and agricultural plastic mulch is considered as the larger contributor than the organic manure input. 


\section{Discussion and Conclusions}

\subsection{Agricultural Input Intensity and Surface Water Quality Risk}

Land use/land cover management, particularly high-input agriculture, is considered to be an important source of pollution export from catchments and frequently has been identified as a major contributor of surface water pollution [26]. The above results and analysis provide insight into the linkages between agricultural land use intensity and regional surface water quality. For the Beijing mountainous study area, several groups of agricultural input affecting surface water quality were identified during the year 2000. The results indicated that the explanatory variables behind the various water quality indexes were quite different at the respective significant watershed scales. The view that nitrate may be a useful general indicator of intensive land use was supported by previous work by Hunt et al [27]. As in Hunt [27], nitrate in particular can be considered as a useful indicator of intensive natural factors and agricultural chemical fertilizer input at the significant watershed scale in the Beijing mountainous areas. The input intensity of pesticide and agricultural plastic mulch in the Beijing mountainous areas watersheds has increased drastically between 1984 and 2000, which resulted in the permanganate index pollution risk. Several studies have indicated that the proportion of vegetable-planted land exhibited a positive correlation with permanganate index [28]. For the Beijing mountainous areas, vegetable outputs depended principally on the abundant inputs of pesticide and agricultural plastic mulch in 2000, according to our previous research [24].

\subsection{Watershed Adaptive Response Unit}

The significant scales at which there were statistically significant relationships between agricultural land use intensity and each water quality variable were identified on the basis of the multi-scale regression analysis, which were considered as the watershed adaptive response units for each water quality variable. Thus, the first order watershed (Zone 1) of 27 monitoring points was the adaptive response unit for nitrate-nitrogen, while the fifth order watershed (Zone 5) was the adaptive response unit for the permanganate index.

In the Beijing mountainous study area, watershed adaptive response units differ with the water quality variables being assessed, which are related with transformation regularity of nitrate-nitrogen and permanganate index. After the use of nitrate fertilizer that is the source of nitrate-nitrogen on agricultural fields, nitrate-nitrogen formed by nitrification is either absorbed and utilized by plants or transformed into gaseous nitrogen through denitrification under reducing conditions. Therefore, only the agricultural inputs inside the first order watershed zones can make a significant contribution to the concentration of nitrate-nitrogen at the pour-point, while that inside other order watershed zones has little influence on the nitrate-nitrogen level at the pour-point with the action of long distance transport.

Compared to nitrate-nitrogen, permanganate index contamination is relatively steady. As the main source, the transformation time of agricultural plastic mulch and pesticides is relatively long. It could not make a significant contribution to the concentration of permanganate index until it accumulates. Therefore, the smaller area basins, such as first order watershed to the fourth order watershed, hardly respond to permanganate index as a contributing zone. 
The definition of watershed adaptive response unit based on the basic watershed units, actually a contributing zone, is very meaningful for the purpose of more effective watershed management. It is important to address the fine-scale management issues relate to watershed adaptive response units for every water quality parameter. The adjustment of agricultural input structure and intensity may be carried out inside the individual watershed adaptive response units.

\subsection{Modeling}

The multiple linear regression model performed using log transformed dependent variables, which was adopted in many previous studies to explore the relationship between land use and stream water, can also provide insight into the linkages between agricultural land use intensity and stream water quality at multiple watershed scales. The statistical models in this study are valuable in examining the relative sensitivity of water quality indexes to alterations in agricultural land use intensity inside the various contributing zones when coupled with expert knowledge. The modeling results can also further help to identify the cause-and-effect relationships between agricultural input intensity and stream water quality inside the watershed adaptive response units, which are important in the management of water quality. The modeling, although statistically significant, showed the relatively weak coefficients of determination. It may be that the spatial incompatibility between the watershed spatial unit and the municipal/town unit was actually existed, or that other potential factors influencing stream water quality variable were not included in the analysis. All of these are worthy of further research.

Although multiple linear regression models are an effective approach for identifying significant agricultural input intensity affecting water quality and explaining the relationship between agricultural land use intensity and stream water quality, they do not appear to quantitatively estimate contribution of respective agricultural land use intensity on the water quality because they are only based on the existence of statistical significance in the analysis data, rather than any mechanistic relationships between sources and receptors. Our future research will focus on understanding the exact mechanisms of the effect of agricultural land use intensity on stream water quality by adopting an alternative "sources-receptors model" based on the mass balance approach.

\section{Acknowledgments}

The research was supported by Beijing Natural Science Foundation (8122020). The authors are grateful to the Beijing Municipal Bureau of Water Management for their water sampling and analysis, and we would like to thank all reviewers and editors for their valuable comments and suggestions during the review process.

\section{Conflict of Interest}

The authors declare no conflict of interest.

\section{References}

1. Lambin, E.F.; Rounsevell, M.D.A.; Geist, H.J. Are agricultural land-use models able to predict changes in land-use intensity? Agr. Ecosyst. Environ. 2000, 127, 321-331. 
2. Tilman, D. Global environmental impacts of agricultural expansion: The need for sustainable and efficient practices. Proc. Nat. Acad. Sci. USA 1999, 96, 5995-6000.

3. Bouwman, A.F.; Booij, H. Global use and trade of feedstuffs and consequences for the nitrogen cycle. Nutr. Cycl. Agroecosys. 1998, 52, 261-267.

4. Medema, G.J.; van Asperen, I.A.; Havelaar, A.H. Assessment of the exposure of swimmers to microbiological contaminants in fresh waters. Water Sci. Technol. 1997, 35, 157-163.

5. Tong, S.T.Y.; Chen, W. Modeling the relationship between land use and surface water quality. J. Environ. Manage. 2002, 66, 377-393.

6. Ribolzi, O.; Cuny, J.; Sengsoulichanh, P.; Mousquès, C.; Soulileuth, B.; Pierret, A.; Huon, S.; Sengtaheuanghoung, O. Land use and water quality along a Mekong Tributary in Northern Lao PDR. Environ. Manage. 2011, 47, 291-302.

7. Seeboonruang, U. A statistical assessment of the impact of land uses on surface water quality indexes. J. Environ. Manage. 2012, 101, 134-142.

8. Chaplot, V.; Saleh, A.; Jaynes, D.B.; Arnold, J. Predicting water, sediment and $\mathrm{NO}_{3}-\mathrm{N}$ loads under scenarios of land-use and management practices in a flat watershed. Water Air Soil Pollut. 2004, 154, 271-293.

9. Cao, W.; Bowden, W.B.; Davie, T.; Fenemor, A. Modelling impacts of land cover change on critical water resources in the Motueka River catchment, New Zealand. Water Resour. Manag. 2009, 23, 137-151.

10. Bhattarai, G.; Srivastava, P.; Marzen, L.; Hite, D.; Hatch, U. Assessment of economic and water quality impacts of land use change using a simple bioeconomic model. Environ. Manage. 2008, $42,122-131$.

11. Rhodes, A.L.; Newton, R.M.; Pufall, A. Influences of land use on water quality of a diverse New England watershed. Environ. Sci. Technol. 2001, 35, 3640-3645.

12. Li, S.; Gu, S.; Tan, X.; Zhang, Q. Water quality in the upper Han River basin, China: The impacts of land use/land cover in riparian buffer zone. J. Hazard. Mater. 2009, 165, 317-324.

13. Mattikalli, N.M.; Richards, K.S. Estimation of surface water quality changes in response to land use change: Application of the export coefficient model using remote sensing and geographical information system. J. Environ. Manage. 1996, 48, 263-282.

14. Xiao, H.; Ji, W. Relating landscape characteristics to non-point source pollution in mine waste-located watersheds using geospatial techniques. J. Environ. Manage. 2007, 82, 111-119.

15. Wang, X. Integrating water-quality management and land-use planning in a watershed context. J. Environ. Manage. 2001, 61, 25-36.

16. Bahar, M.M.; Ohmori, H.; Yamamuro, M. Relationship between river water quality and land use in a small river basin running through the urbanizing area of Central Japan. Limnology 2008, 9 , $19-26$.

17. Kang, J.H.; Lee, S.W.; Cho, K.H.; Ki, S.J.; Cha, S.M.; Kim, J.H. Linking land-use type and stream water quality using spatial data of fecal indicator bacteria and heavy metals in the Yeongsan river basin. Water Res. 2010, 44, 4143-4157.

18. Liu, Z.; Li, Y.; Li, Z. Surface water quality and land use in Wisconsin, USA-A GIS approach. J. Integr. Environ. Sci. 2009, 6, 69-89. 
19. Basnyat, P.; Teeter, L.D.; Lockaby, B.G.; Flynn, K.M. The use of remote sensing and GIS in watershed level analyses of non-point source pollution problems. For. Ecol. Manage. 2000, 128, 65-73.

20. Sliva, L.; Williams, D.D. Buffer zone versus whole catchment approaches to studying land use impact on river water quality. Water Res. 2001, 35, 3462-3472.

21. Maillard, P.; Pinheiro Santos, N.A. A spatial-statistical approach for modeling the effect of non-point source pollution on different water quality parameters in the Velhas river watershed-Brazil. J. Environ. Manage. 2008, 86, 158-170.

22. Jung, K.W.; Lee, S.W.; Hwang, H.S.; Jang, J.H. The effects of spatial variability of land use on stream water quality in a costal watershed. Paddy Water Environ. 2008, 6, 275-284.

23. Wu, Q.; Li, H.Q.; Wang, R.S.; Paulussen, J.; He, Y.; Wang, M.; Wang, B.H.; Wang, Z. Monitoring and predicting land use changes in Beijing using remote sensing and GIS. Landsc. Urban Plan 2006, 78, 322-333.

24. Zhang, W.W.; Li, H.; Huo, X.N.; Sun, D.F.; Zhou, L.D. Agricultural land use intensity based on emergy analysis (in Chinese, with English abstract). Trans. CSAE 2009, 25, 204-210.

25. Phillips, J.D. Evaluation of North Carolina's estuarine shoreline area of environmental concern from a water quality perspective. Coast. Manage. 1989, 17, 103-117.

26. Hoorman, J.; Hone, T.; Sudman, T.; Dirksen, T.; Iles, J.; Islam, K.R. Agricultural impacts on lake and stream water quality in Grand Lake St. Marys, Western Ohio. Water Air Soil Pollut. 2008, 193, 309-322.

27. Hunt, J.W.; Anderson, B.S.; Phillips, B.M.; Tjeerdema, R.S.; Richard, N.; Connor, V.; Worcester, K.; Angelo, M.; Bern, A.; Fulfrost, B.; et al. Spatial relationships between water quality and pesticide application rates in agricultural watersheds. Environ. Monit. Assess. 2006, 121, 243-260.

28. Li, S.; Gu, S.; Liu, W.; Han, H.; Zhang, Q. Water quality in relation to land use and land cover in the upper Han River Basin, China. Catena 2008, 75, 216-222.

(C) 2012 by the authors; licensee MDPI, Basel, Switzerland. This article is an open access article distributed under the terms and conditions of the Creative Commons Attribution license (http://creativecommons.org/licenses/by/3.0/). 